Original Research Paper

\title{
Pembinaan Cara Beternak untuk Meningkatkan Produktifitas Ternak Sapi Pada Program 1000 Desa Sapi di Desa Teruwai Kabupaten Lombok Tengah
}

\author{
Yusuf Akhyar Sutaryono ${ }^{*}$, Ikmal Maulana ${ }^{2}$, Muhammad Habibi $^{3}$ Dimas Bayu Utomo $^{4}$ \\ 1. Fakultas Peternakan Universitas Mataram \\ 2. Program Studi Sosiologi Universitas Mataram \\ 3. Fakultas Ekonomi dan Bisnis Universitas Mataram \\ 4. Fakultas Teknologi Pangan dan Agroindustri Universitas Mataram
}

https://doi.org/10.29303/jpmpi.v3i2.989

Sitasi: Sutaryono, Y. A., Maulana, I., Habibi, M \& Utomo, D. B. (2021). Pembinaan Cara Beternak untuk Meningkatkan Produktifitas Ternak Sapi Pada Program 1000 Desa Sapi di Desa Teruwai Kabupaten Lombok Tengah. Jurnal Pengabdian Magister Pendidikan IPA, 4(3)

\section{Article history}

Received: 1 September 2021

Revised: 22 September 2021

Accepted: 23 September 2021

*Corresponding Author:

Yusuf Akhyar

Sutaryono, Fakultas

Peternakan, Universitas

Mataram, Mataram, Indonesia

Email: ysf_25@yahoo.com

\section{Pendahuluan}

Pangan adalah segala sesuatu yang berasal dari sumber hayati produk pertanian, perkebunan, kehutanan, perikanan, peternakan, perairan, dan air, baik yang diolah maupun tidak diolah yang diperuntukkan sebagai makanan atau minuman bagi konsumsi manusia,termasuk bahan tambahan

\begin{abstract}
Program 1000 desa sapi adalah upaya peningkatan populasi dan produktifitas ternak sapi dalam rangka swasembada daging untuk mencapai ketahanan pangan nasional. Salah satu desa yang menjadi pilot projek dari program ini adalah Desa Teruwai, Kecamatan Pujut, Kabupaten Lombok Tengah. Kondisi yang ada pada peternak disini adalah masih menerapkan sistem peternakan tradisional, dimana ternak sapi dipelihara dan diberi makan dengan pakan yang tidak berpedoman pada kecukupan kualitas nutrisi, sehingga menyebabkan rendahnya produktifitas sapi. Untuk mengatasi masalah ini, dilakukan pembinaan bagaimana cara beternak yang ideal dengan memberikan pelatihan pembuatan pakan ternak berkualitas, pelatihan perawatan ternak, pelatihan pengolahan limbah ternak, serta pelatihan manajemen pengadaan pakan yang cukup dan berkualitas. Pembinaan cara beternak yang ideal merupakan suatu upaya perbaikan sistem peternakan sapi yang lebih efektif dan lebih efisien untuk menghasilkan ternak yang berproduksi tinggi sehingga usaha swasembada daging dapat dicapai sehingga terciptalah ketahanan pangan nasional. Hasil yang di dapat dengan adanya pelatihan-pelatihan yang dilakukan para peternak sudah mulai menggunakan sistem beternak yang lebih modern, memperbaiki kualitas pakan yang digunakan, mulai melakukan pengolahan limbah ternak sapi menjadi kompos dan biogas, serta dapat menerapkan manajemen pengadaan pakan yang optimal.
\end{abstract}

Keywords: 1000 Desa Sapi, produktifitas ternak, cara beternak, manajemen pakan, kompos

pangan, bahan baku pangan, dan bahan lainnya yang digunakan dalam proses penyiapan, pengolahan, dan/atau pembuatan makanan atau minuman. Berdasarkan Undang-Undang (UU) No. 18 Tahun 2012 tentang Pangan, disebutkan bahwa yang dimaksud dengan ketahanan pangan adalah kondisi terpenuhinya pangan bagi negara sampai dengan perseorangan, yang tercermin dari 
tersedianya pangan yang cukup, baik jumlah maupun mutunya, aman, beragam, bergizi, merata, dan terjangkau serta tidak bertentangan dengan agama, keyakinan, dan budaya masyarakat, untuk dapat hidup sehat, aktif, dan produktif secara berkelanjutan.

Daging sapi merupakan salah satu bahan pangan asal ternak yang menjadi sumber protein hewani yang paling digemari masyarakat. Tingginya permintaan pasar akan daging saat ini tidak dapat dipenuhi oleh produksi daging dalam negeri sehingga sampai saat ini pemerintah masih mengandalkan impor daging yang cukup tinnggi. Dalam rangka mewujudkan pencapaian ketahanan pangan dan meningkatkan produksi daging nasional, Kementrian Pertanian melalui Jendral Peternakan dan Kesehatan Hewan (Ditjen PKH) Kementerian Pertanian RI merancang Program 1000 Desa Sapi. Program 1000 Desa Sapi dilakukan dalam upaya meningkatkan produktiviras sapi dan kesejahteraan peternakan yang diimplementasikan di lima provinsi yakni Lampung, Jawa Timur, Nusa Tenggara Barat, Nusa Tenggara Timur, dan Sulawesi Selatan.

Di provinsi Nusa Tenggara Barat lokasi pilot project program 1000 Desa Sapi berada di Kecamatan Pujut, Kabupaten Lombok Tengah dengan mengambil lokasi di lima desa yaitu Teruwai, Pengengat, Mertak, Bangket Parak dan Sukadana. Alasan penempatan program 1000 desa sapi di Kecamatan Pujut adalah selain potensi tersedianya pakan di kecamatan ini disamping itu juga karena desa desa dikecamatan ini menjadi penyangga untuk daerah pusat pariwisata Mandalika. Lima desa penerima program 1000 Desa Sapi masing-masing memiliki lahan hijau pakan ternak yang diharapkan dapat menyediakan pakan yang cukup bagi ternak sapi yang dipelihara. Disamping itu, untuk mendukung program 1000 Desa Sapi ini, pemerintah juga mengembangkan program bank pakan yang berada di Dusun Batu Guling desa Mertak yang akan mengolah hijauan pakan dalam bentuk silase yang dibungkus plastik kedap udara (baler). Namun karena terkendala jarak yang cukup jauh dan menghabiskan cukup banyak biaya transportasi maka peternak memilih untuk menyediakan pakan ternak sendiri untuk memenuhi kebutuhan pakan ternak mereka.

Desa Teruwai sebagai salah satu lokasi program 1000 desa sapi memiliki populasi sapi yang tinggi dan memiliki ketersediaan hijauan yang cukup untuk ternak yang ada. Peternak yang berada di desa Teruwai memilih untuk menyediakan bahan pakan yang mereka miliki secara mandiri dan menggunakan sistem yang masih terbilang tradisional. Ketersedian pakan yang cukup terutama pada musim kemarau yang panjang juga masih menjadi masalah sulit di daerah ini. Keterbatasan lain dari peternak di desa Teruwai belum terlalu memahami bagaimana sistem beternak baik. Demikian pula dalam manajemen pakan maupun pengolahan limbah ternak yang dihasilkan, sehingga kondisi pemeliharaan ternak saat ini adalah belum mampu mengatasi masalah yang timbul dari kotoran ternak dan sisa pakan dikandang. Menilik hal ini maka dirasa perlu melakukan pelatihan manajemen penyediaan dan pemberian pakan serta pengolahan limbah ternak untuk mengoptimalisasi program 1000 Desa Sapi di Desa Teruwai, Kecamatan Pujut, Kabupaten Lombok Tengah.

\section{Metode}

Pelatihan pembinaan cara beternak untuk peternak di Desa Teruwai sebagai lokasi program 1000 Desa Sapi dilaksanakan dengan metode pendekatan sosialisasi dan praktik yang dikemas dalam bentuk pelatihan-pelatihan kepada para peternak. Metode ini ditujukan untuk mendampingi serta memfasilitasi peternak untuk belajar tata cara dalam beternak yang ideal sehingga peternakan yang dilakukan dapat memberikan hasil yang memuaskan serta tidak memberikan dampak negative. Metode analisis data kebutuhan peternak dilakukan dengan metode observasi dan wawancara. Hal ini ditujukan untuk mengetahui bagaimana kondisi fisik jalannya usaha peternakan dengan mengamati secara langsung dilapangan. Pengumpulan informasi kemudian dilanjutkan dengan menggali informasi yang lebih detail dengan memanfaatkan informan kunci untuk diwawancarai. Dengan demikian dapat disimpulkan permasalahan-permasalahan yang dihadapi oleh peternak dan untuk dapat dicarikan solusi yang tepat untuk mengatasi masalahmasalah yang ada guna mencapai keberhasilan program 1000 Desa Sapi di Desa Teruwai, Kecamatan Pujut, Kabupaten Lombok Tengah 
Pelaksanaan kegiatan pengabdian dengan pelatihan dan demonstrasi dilakukan dengan pentahapan sebagai berikut:

\subsection{Tahap Persiapan.}

Pada tahap persiapan ini telah dilakukan penjajakan ke kelompok peternak " Tunas Karya II" yang ada di desa Teruwai Kecamatan Pujut Kabupaten Lombok Tengah. Segala hal yang terkait dengan pelaksanaan kegiatan pada tahap ini telah disiapkan untuk menjamin kelancaran pelaksansan kegiatan pengabdian ini. Bahan dan alat yang dibutuhkan serta jadwal pelaksanaan, tempat pelaksanaan dan jumlah peserta yang akan terlibat dalam kegiatan ini juga dipastikan dalam tahap ini. Koordinasi kegiatan pengabdian ini dilakukan langsung dengan ketua kelompok petemak mitra dan anggota-anggotanya. Dalam hal ini difokuskan untuk pengembangan program 1000 Desa Sapi di desa Teruwai.

\subsection{Tahap Pelaksanaan.}

Pelaksanan program pengabdian di kelompok petemak mitra ini dilakukan dengan metode: ceramah, materi tertulis dan demonstrasi. Melalui metode ceramah telah disampaikan dengan memberikan pengertian dan penjelasan kepada para peternak mengenai manajemen pemberian pakan berkualitas dan jenis hijauan pakan yang dapat dijadikan sebagai pakan ternak berkualitas. Metode tertulis disampaikan pemberian bahan tertulis yang disampaikan dengan alat bantu LCD dan presentasi power point tentang pakan berkualitas, sekaligus dengan memberikan diktat/brosur tentang contoh-contoh hijauan pakan berkualitas. Sedangkan metode demonstrasi, para peternak langsung mempraktekkan cara menyusun dan pemberian pakan ternak sapi yang berkualitas dan cara pembuatan kompos dari kotoran ternak.

Penyampaian materi pengabdian dilakukan oleh seluruh anggota tim pengabdian yang terlibat dalam kegiatan ini. Adapun materi dan penyuluhan dan demonstrasi pada program pengabdian kepada masyarakat ini adalah sebagai berikut:
a. Manajemen penyediaan dan pemberian pakan berkualitas
b.Pengenalan macam-macam hijauan (rumput dan legum) bahan penyusun pakan ternak c. Demonstrasi penyusunan pakan berkualitas

d. Cara pembuatan kompos dari kotoran ternak

e. Cara pembibitan dan penanaman legume Lamtoro

\section{Hasil dan Pembahasan}

\section{A. Manajemen Penyediaan dan Pemberian Pakan Berkualitas}

Seperti halnya dengan peternak-peternak di desa lainnya di Pulau Lombok, pemeliharaan ternak secara tradisional di Desa Teruwai Kecamatan Pujut Kabupaten Lombok Tengah masih dilakukan dengan pemberian pakan seadanya tanpa pernah menghitung kecukupan jumlah maupun nutrisi yang ada dalam ransum ternaknya. Kebutuhan hijauan pakan ternak sebagian besar dipenuhi dari sumber-sumber hijauan yang ada yaitu rumput/hijauan yang tumbuh pada pematangpematang sawah, kebun ataupun tegalan serta dengan memanfaatkan hasil sisa tanaman pertanian/limbah terutama pada saat musim panen.

Ketersediaan hijauan pakan ternak di desa ini sangat dipengaruhi oleh musim. Pada saat musim hujan peternak tidak merasa kesulitan dalam memenuhi kebutuhan hijauan pakan ternaknya, pada musim hujan hijauan pakan ternak tersedia cukup melimpah bahkan melebihi kebutuhan ternak yang ada. Sebaliknya pada saat musim panas/kemarau terutama 2 (dua) bulan terakhir dimusim kemarau peternak merasa sangat kesulitan dalam memenuhi kebutuhan pakan ternaknya, dimana peternak hanya memberikan sisa- sisa limbah pertanian. Hal tersebut bila berlangsung lama tentu akan menyebabkan terjadinya kerugian yang akan dialami oleh peternak karena kondisi tersebut selain akan mengakibatkan terjadinya penurunan berat badan, produktivitas ternak juga akan menurun.

Berdasarkan pada analisis situasi yang ada di Desa Teruwai, dapat dilihat bahwa permasalahannya bahwa rendahnya produktivitas ternak yang dipelihara disebabkan karena pemberian pakan masih dilakukan secara tradisional tanpa pernah mempertimbangkan kecukupan jumlah kebutuhan bahan kering ransum maupun kandungan nutrisinya. Hal tersebut selain disebabkan karena keterbatasan pengetahuan dan ketrampilan peternak dalam melakukan penyusunan ransum, juga disebabkan karena keterbatasan pengetahuan dan keterampilan 
peternak dalam melakukan pengolahan dan pengawetan pakan yang akan menjamin kontinyuitas ketersediaan bahan pakan. Pemecahan masalah dengan memberikan penyuluhan dan demonstrasi meningkatkan pengetahuan dan ketrampilan peternak dalam melalukan manajmen pemberian pakan berkualitas untuk ternak sapi yang dipelihara. Dengan menguasai manajemen yang baik maka peternak dapat meningkatkan produktifitas ternak sapi mereka dan akan menghasilkan termak sapi yang lebih cepat pertumbuhannya dan lebih besar kenaikan berat badanya sehingga akan mendapatkan ternak yang berkualitas dan dapat dijual dengan harga yang tinggi.

Menghadapi permasalahan tersebut, peternak telah dibekali pengetahuan dan ketrampilan dalam manajemen pemberian pakan berkualitas bagi ternak sapi yang mereka pelihara. Disamping itu untuk menjamin kontinyuitas ketersediaan bahan pakan dan untuk menyusun dan memberikan pakan berkualitas bagi ternaknya peternak juga perlu mendapatkan tambahan pengetahuan jenis-jenis dan cara pemeliharaan hijauan pakan ternak berkualitas yang dapat dibudidayakan dilahan pertanian yang mereka miliki. Demikian pula peternak diberikan pengetahuan tentang teknologi pemanfaatan dan pengolahan limbah pertanian (Komar, 1984), dan teknologi penyimpanan hijauan pakan ternak berkualitas (Soedomo, R. 1995).

Pengetahuan tentang jenis-jenis hijauan pakan ternak berkualitas serta cara penanaman dan pemeliharaan tanaman hijauan pakan akan menjamin peternak dalam penyediaan hijauan pakan untuk memenuhi kebutuhan ternak baik dalam kuantitas maupun kualitas. Teknologi pemanfaatan dan pengolahan limbah pertanian juag akan memberikan peluang bagi peternak untuk menambah persediaan hijauan pakan bagi ternak mereka. Terutama dalam mengatasi kekurangan hijaua pakan pada musim kemarau (Sutaryono, 2021a). Semua peternak terlihat sangat antusias mengikuti materi pelatihan yang disampaikan karena mereka merasa materi yang diberikan akan memberikan manfaat bagi meraka dalam pemelihraan ternaknya. Mereka mengerti bahwa penyedian dan pemberian pakan yang berkualitas akan mengatasi masalah terbatasnya ketersediaan pakan yang mereka hadapi dan sekaligus akan meningkatkan produktifitas ternak yang mereka miliki. Peternak dengan aktif terlibat dalam diskusi dan Tanya jawab yang berlangsung selama penyampaian materi penyuluhan dan pelatihan.

\section{B. Pembuatan Kompos dari kotoran ternak dan sisa pakan (limbah ternak)}

Limbah merupakan bahan organik atau anorganik yang tidak termanfaatkan lagi sehingga dapat menimbulkan masalah serius bagi lingkungan jika tidak ditangani dengan baik. Limbah ini dapat berupa limbah padat, cair dan gas yang apabila tidak ditangani dengan baik akan berdampak buruk pada lingkungan. Limbah yang berasal dari peternakan tersebut akan bernilai ekonomi tinggi apabila diolah dengan perlakuan yang tepat. Ada banyak cara yang dapat dilakukan untuk mengolah limbah peternakan tersebut. Terdapat tiga pilihan dalam memanfaatkan limbah kotoran ternak dan sisa pakan ternak yaitu : menggunakan kotoran dan sisa pakan ternak sebagai kompos, sebagai penghasil biogas, dan sebagai bahan pembuat bio arang. Zat-zat yang terkandung dalam kotoran ternak dapat dimanfaatkan kembali dengan mengaplikasikannya pada media tanam setelah melalui ptoses pengomposan. Pengolahan limbah kotoran sapi yang biasa kita jumpai dan cendrung sederhana yaitu kompos.

Kompos merupakan bahan organic, seperti seresah tanaman ataupun tumbuhan yang masih segar seperti rumput-rumputan, serta kotoran hewan yang telah mengalami proses dekomposisi oleh mikroorganisme pengurai, sehingga dapat dimanfaatkan untuk memperbaiki sifat-sifat tanah. Selain dapat memperbaiki sifat-sifat tanah kompos juga berfungsi sebagai sumber bahan organik atau sumber hara yang sangat dibutuhkan oleh tanaman. Potensi feses atau kotoran ternak yang dapat dimanfaatkan sebagai pupuk sangat tinggi seiring dengan meningkatnya populasi sapi.

Proses pengomposan adalah proses dimana bahan organik mengalami penguraian secara biologis, khususnya oleh mikroba yang memanfaatkan bahan organik sebagai sumber energi. Pembuatan pupuk kompos juga merupakan salah satu alternative pemecahan masalah pencemaran lingkungan dan juga dapat menambah penghasilan jika dikomersialkan. Pembuatan kompos ini dilandasi atas kehawatiran terhadap masalah limbah ternak 
yang belum bisa dikelola dengan baik oleh para peternak. Selain itu, kurangnya minat masyarakat dalam mengatasi limbah ternak menjadi masalah tersendiri. Kotoran ternak yang dibiarkan tidak tertangani berpotensi menjadi media yang dapat menyebarkan penyakit bagi ternak dan juga bagi masyarakat peternak. Pembuatan kompos ini ditujukan untuk meningkatkan nilai kebermanfaatan dari kegiatan beternak yang dilakukan, karena limbah kotoran sapi dan sisa pakan yang ada dapat bermanfaat dan memiliki nilai jual bila telah diproses menjadi kompos.

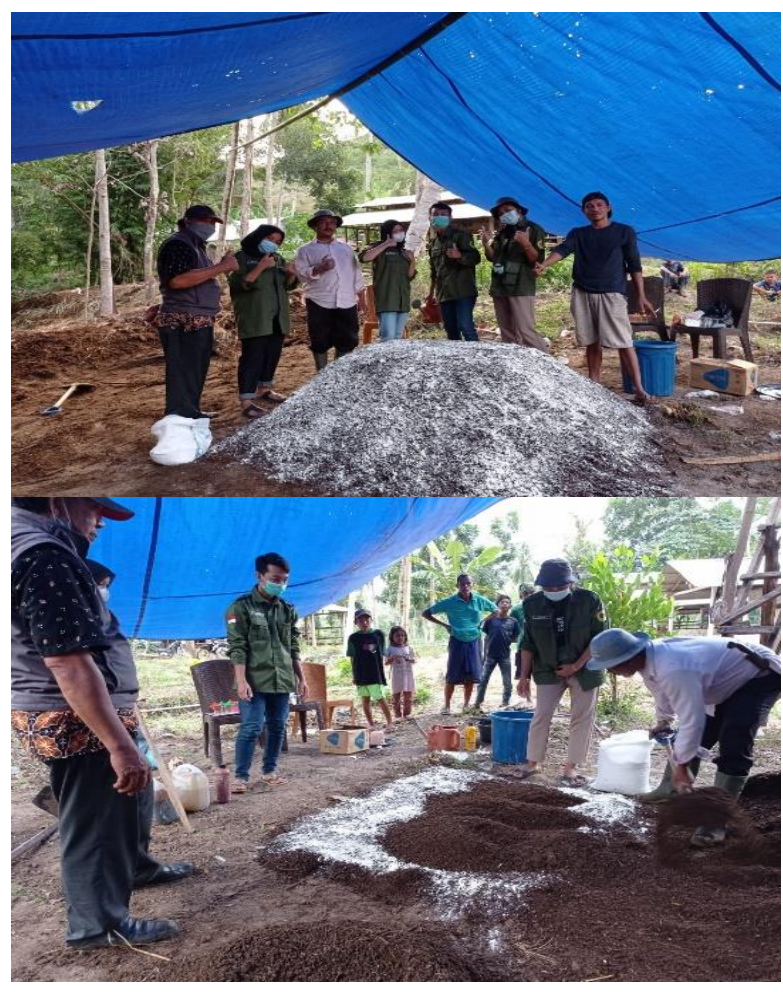

Metode dalam pembuatan kompos ini ada dua cara yaitu pertama dengan melakukan pelatihan pembuatan kompos secara langsung bersama para peternak yang ditujukan agar peternak mampu mengolah kembali kotoran sapi sehingga lebih bermanfaat untuk mengurangi kerusakan lingkungan akibat kotoran sapi yang masih basah serta dapat meminimalisir timbulnya wabah penyakit yang dapat menyerang ternak sapi maupun peternak seperti malaria dan demam berdarah Dengue.

Demonstrasi yang kedua ditunjukkan dengan cara pengaplikasian pemanfaatan kompos sebagai media tanam. Hal ini dilakukan dengan menunjukkan secara langsung penggunaan kompos pada sebagai media tanam untuk tanaman pertanian seperti sayur-sayuran. Dengan demikian masyarakat sekitar sadar bahwa kompos bukan hanya wacana untuk mengurangi limbah kotoran sapi yang ada namun kompos ini merupakan suatu olahan limbah kotoran sapi dan sisa pakan ternak yang dapat meningkatkan produksi dan kualitas dari hasil pertanian.

Pada pengaplikasian kompos ditunjukkan dengan memanfaatkan areal sekitar kandang sapi untuk menjadi lahan percobaan dengan melakukan kegiatan bertani tanaman sayursayuran. Dengan menggunakan kompos sebagai pupuk organik dalam menanam tanaman sayursayuran diharapkan dapat menghasilkan produktivitas tanaman lebih berkualitas. Hal ini akan mampu memberikan edukasi kepada para peternak untuk termotivasi dalam mengolah kotoran atau limbah ternak menjadi kompos yang diketahui akan bermanfaat untuk kegiatan bertani secara pribadi atau dimanfaatkan untuk diperjual belikan untuk meningkatkan ekonomi masyarakat sekitar.

Hasil yang diperoleh dari diadakannya pelatihan pembuatan kompos pada Kelompok Ternak Sapi Tunas Karya II yang dilaksanakan bersama petugas pendamping program 1000 Desa Sapi Kabupaten Lombok Tengah ialah para peternak mampu mengolah kembali kotoran sapi sehingga lebih bermanfaat untuk mengurangi kerusakan lingkungan akibat kotoran sapi yang masih basah serta dapat meminimalisir timbulnya wabah penyakit. Selain itu, juga para pertenak dapat mengetahui bagaimana pengaplikasian kompos beserta manfaatnya untuk keberlangsungan hidup yang lebih sejahtera.

\section{Pembibitan dan penanaman legume Lamtoro}

Penyemaian lamtoro dilatar belakangi oleh adanya masalah yang di hadapi oleh para peternak, yaitu kurangnya ketersediaan pakan di musim kemarau dan produktivitas dan kualitas ternak belum maksimal. Pada saat kondisi normal ketika musim hujan dan awal musim kemarau, peternak menggunakan rumput gajah dan rumput alam yang melimpah sebagai pakan ternak. Namun pada saat musim kemarau rumput Gajah dan rumput alam tidak bisa mencukupi menjadi pakan ternak karena rendahnya produksi 
karena terbatasnya air tanah. Rumput embutuhkan banyak air untuk bisa tumbuh dan berproduksi dengan dengan baik sehinga tidak dapat meningkatkan produktifitas dan kualitas ternak. Untuk mengatasi kekurangan ketersediaan pakan ternak dimusim kemarau ini maka ehingga solusi untuk masalah ini yaitu dengan penanaman tanaman pakan ternak yang dapat tumbuh dan berproduksi dengan baik selama musim kemarau yaitu dengan menanam tanaman legume pohon lamtoro. Para peternak dilatih untuk menanam dan merawat tanaman legume lamtoro sebagai peneydia pakan ternak dimusim kemarau. Pelatihan mencakup membuat penyemaian bibit lamtoro dalam bedengan, pemindahan tanaman dengan membuat stump dan pindah tanam tanaman lamtoro ke lahan tanam.

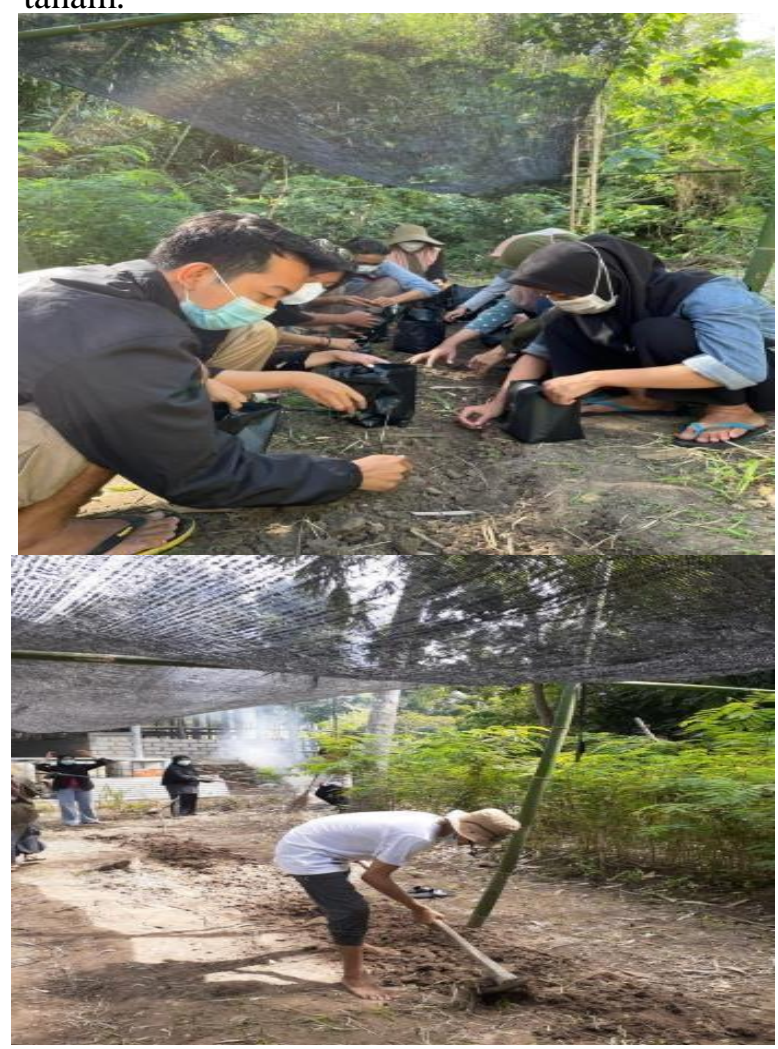

Persemaian adalah tempat untuk kegiatan memproses benih menjadi bibit yang siap di tanam di lapangan. Penyemaian lamtoro merupakan slangkah awal untuk merealisasikan penanaman dan penggunan lamtoro sebagai pakan ternak. Lamtoro adalah salah satu jenis polong - polongan serbaguna yang paling banyak ditanam dalam pola pertanaman campuran (wanatani). Tanaman lamtoro memiliki banyak manfaat yaitu sebagai tanaman sumber protein untuk ternak ruminansia, sebagai pencegah erosi, tanaman pagar hidup dan tanaman pelindung. Lamtoro memiliki kandungan protein kasar yang sangat tinggi yaitu sekitar 34\%. Tanaman lamtoro sangat disukai oleh ternak, pertumbuhannya cepat dan mudah di daerah tropis. Kandungan nutrisi lamtoro yaitu serat kasar $18 \%$ dan lemak kasar 5,8\%. Lamtoro pada dasarnya termasuk tanaman yang mudah beradaptasi, sehingga membudidayakannya tergolong mudah (Sutaryono, 2021). Pakan lamtoro cocok tumbuh di cuaca yang panas dan minim air. Lamtoro mempunyai pertumbuhan yang cepat dan dapat tumbuh dengan baik di daerah dengan curah hujan tahunan $650 \mathrm{~mm}$ sampai $3000 \mathrm{~mm}$. Tanaman ini toleran terhadap iklim kering atau yang memiliki curah hujan 300 mm dengan periode kekeringan 6 sampai 7 bulan sehingga sangat cocok dikembangkan di daerah kering beriklim kering. Lamtoro sangat cocok dipakai untuk pakan penggemukan karena kandungan nutrisinya yang tinggi sehingga dapat memenuhi kebutuhan nutrisi penggemukan.

Dalam kegiatan penyemaian, hal pertama yang di lakukan adalah penentuan lokasi penyemaian. Ada 3 lokasi penyemaian yang sudah di tetapkan, setelah dilakukan diskusi dengan ketua ternak maka di putuskan untuk 3 lokasi tersebut memiliki penanggung jawab masing-masing, yaitu para peternak di bagi menjadi 3 kelompok dimana 1 kelompok bertanggung jawab pada 1 lokasi penyemaian. Tahap kedua yaitu seleksi benih, Benih yang akan di semai harus memiliki kualitas yang bagus sehingga bisa tumbuh dengan baik, Ciriciri benih yang baik yaitu kering di pohon, tenggelam apabila di rendam air, dan besarnya seragam. Tahap ketiga yaitu persiapan media tanam, Media semai yang di perlukan dalam kegiatan penyemaian yaitu tanah : pupuk kandang : pasir dengan perbandingan 1:1:1. Namun karena tanah di lokasi persemaian cukup gembur sehingga tidak di perlukan campuran pasir. Penyemaian lamtoro di lakukan melalui persemaian menggunakan bedengan (bed seeded).

Pembuatan bedengan dilakukan dekat dengan lokasi penanaman. Adapun keuntungan dari persemaian bedengan antara lain: pertumbuhan lebih baik dan seragam, perwatannya mudah, dan efesien dalam penggunaan tenaga. Sedangkan 
untuk kegiatan penanaman lamtoro dilakukan di bukit-bukit yang berada di sekitar kandang. Kegiatan penanaman di lakukan secara langsung oleh para peternak peternak. Dengan adanya penyemaian dan penanaman lamtoro ini maka dapat teratasinya kedua masalah para peternak, yaitu dapat tersedianya pakan pada saat musim kemarau dan dapat meningkatkan produktivitas dan kualitas ternak.

\section{Kesimpulan}

Berdasarkan uraian di atas, maka dapat disimpulkan beberapa hal sebagai berikut:

1. Peternak memahami bahwa dengan penguasaan manajemen penyediaan dan pemberian pakan yang berkualitas dan kontinu dapat mengatasi masalah kekurangan pakan dimusim kemarau dan akan dapat meningkatkan produktifitas ternak sapi yang mereka miliki

2. Pembuatan kompos dengan menggunakan kotoran ternak dan sisa pakan dikandang dapat meningkatkan kesehatan ternak dan lingkungan kandang serta dapat dijadikan sebagai usaha untuk memperoleh penghasilan tambahan

3. Penanaman legume pohon lamtoro dapat menjadi andalan penyediaan pakan yang berkualitas bagi ternak sapi untuk mengatasi masalah yang dihadapi oleh para peternak yaitu kurangnya ketersediaan pakan di musim kemarau.

4. .Perlu dilakukan pembinaan dan pendampingan yang berkelanjutan bagi para peternak melalui memerankan akademisi untuk membantu peternak meningkatkan produktifitas ternak mereka sangat diperlukan

5. Perlu dilakukan kerjasama yang berkelamjutan antara akademisi dan peternak dengan melibatkan dinas instansi terkait

\section{Daftar Pustaka}

https://www.ntbprov.go.id/post/programunggulan/program-1000-desa-sapintb-songsong- swasambada-daging

https://www.suarantb.com/penggemukansapi-dengan-lamtoro-berpotensimeningkatkan- pendapatanpeternak-hingga-dua-kali-lipat
Komar, A. 1984. Teknologi Pengolahan Jerami Padi Sebagai Makanan Ternak. Yayasan Dian Grahita. Bandung.

Prihandini, P.W. Purwanto, T. Pembuatan Kompos Berbahan Kotoran Sapi. 2007. Pusat Penelitian dan Pengembangan Peternakan. Pasuruan

Soedomo, R., 1995. Forage Conservation. Laboratorium Hijauan Makanan Ternak Fakultas Peternakan Universitas Gajah Mada. Yogyakarta.

Sutaryono YA, Harjono, Mastur dan Sumiati, 2020. Manajemen Pemberian Pakan Berkualitas Di Kelompok Ternak Sapi Pantang Mundur Desa Nyerot Kecamatan Jonggat Lombok Tengah. Seminar Nasional PEPADU II 2020. Lembaga Penelitian dan Pengebdian Pada Masyarakat Universitas Mataram.

Undang-Undang Republik Indonesia Nomer 18 Tahun 2012 Tentang Pangan.

Sutaryono YA. 2021. Pengelolaan Hijauan Pakan Ternak Dalam Sistem Peternakan Rakyat. Deepublish. Yogyakarta. 